\title{
Nature, tourism and landscape assessment of the Lagos Lagoon waterfront
}

\author{
N. Uduma-Olugu \& M. Adebamowo \\ Department of Architecture, University of Lagos, Nigeria
}

\begin{abstract}
Nature, landscape and architecture often find a meeting point in tourism. Globally, tourism has been found to be lucrative and to impact positively on the lives of residents, users and potential users of tourism destinations. Natural water bodies usually attract a lot of visitors as a result of man's affinity to water. If the water body is within the confines of an urban context, several factors may affect their attractiveness, effectiveness and consequently, their patronage. Such factors include the adjoining landscape, land use, the urban context, the architecture of the built environment, core facilities provided, accessibility to venues, sociocultural aspects of the people in the immediate vicinity. Lagos Lagoon waterfront is one such natural body of water which is strategically located in the commercial nerve centre of Nigeria - Lagos. This paper therefore explores its tourism development potentials with respect to its landscape characteristics within the context of its built environment and natural assets. A photo questionnaire which comprises 20 pictures were shown to 422 respondents at six water tourism destinations within the Lagos Lagoon and along the Lagos coast in order to ascertain their preference for the natural aspects versus the built urban context. This enhances a sustained investigation into the role of nature in the tourism development of the area. The results obtained indicates that most pictures selected by the respondents were those of the most developed areas of the lagoon, grassland, and the water body itself. The water was considered as its best asset yet the problems associated with it, like the water quality and other physical attributes were considered as deterrents to its use for tourism. In the same vein, the blights on the water were also identified by the respondents as a hindrance to its beauty and, ultimately, its usage for recreation and tourism.
\end{abstract}

Keywords: nature, tourism, landscape assessment, perception, land use. 


\section{Introduction}

The subject of the study is the Lagos Lagoon, which is part of the Lagos Lagoon complex. The Lagos Lagoon which comprises several lagoons stretching from the Republic of Benin to Nigeria was originally known as Western Nigerian lagoons [1]. Its system consists of a network of nine lagoons. They are: Yewa, Ologe, Badagry, Iyagbe, Lagos, Kuramo, Epe, Lekki, and Mahin as shown in Figure 1 [2]. The Lagos Lagoon, outside being one of the biggest lagoons in Nigeria, is also the largest of the four lagoon systems of the Gulf of Guinea which stretches from about $257 \mathrm{~km}$ from Cotonou in the Republic of Benin to the western edge of the Niger Delta [2]. A coastal lagoon such as that of Lagos Lagoon, refers to an inland body of water, usually parallel to the coast, separated from the ocean by one or more restricted inlets, and having depths which seldom exceed a couple of meters. The boundaries of the Lagos Lagoon are described [3] as: the Southern margin of the Lagos Lagoon is bounded by the Five Cowrie Creeks, the Eastern margin by the Palavar Islands, the Northern border by Ikorodu, and the western border by various mainland communities (Figure 2).

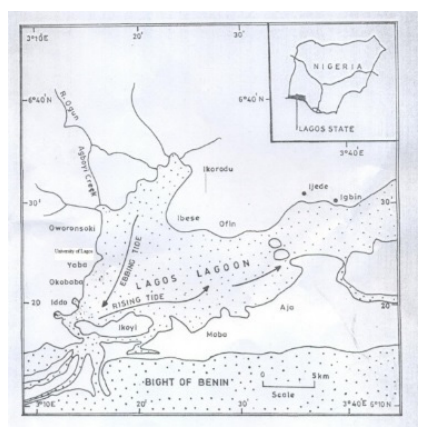

Figure 1: The Lagos Lagoon within Lagos State, Nigeria [2].

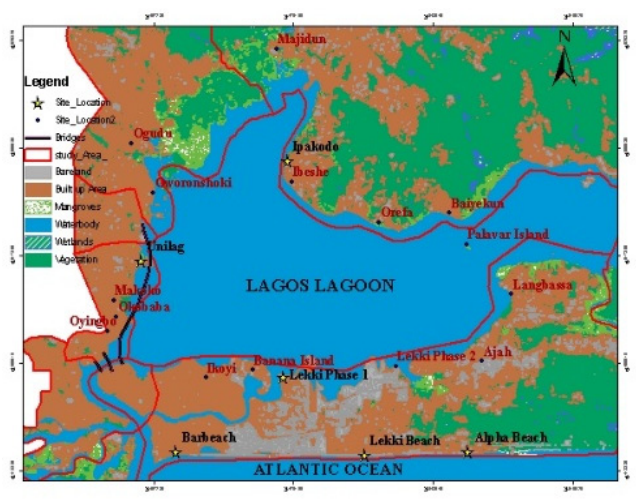

Figure 2: The Lagos Lagoon waterfront communities. (Source: Department of Surveying and Geoinformatics, University of Lagos.) 
As a water body subject to tidal waves, it is directly linked to the Atlantic Ocean on the south. The lagoon continues to the Epe lagoon which eventually opens out to the Atlantic Ocean through the Lagos harbour [2]. Its use for recreation and tourism has been understated. Much research has been done on its state of pollution [4] and its potential for water transport and regeneration [5], but not enough on its tourism development potentials. Its landscape characteristics and other natural features are likely to affect its use for tourism. This study explores the effect of its landscape characteristics and perception by its users and potential users on its potential as a viable tourism destination.

The landscape of a place is the major determinant of its use [6] - as one of the factors that decides its attractiveness to tourists. The elements of landscape are land form, topography, land cover (vegetation), and visual/aesthetic elements [7]. Land use is also part of the characteristic of landscape, as man's imprint on the land determines its character. The three main landscape classifications are - single landscape characteristics (where homogenous areas denote the productivity and quality of the landscape which possess peculiar individual natural resource e.g. soils or vegetation), multiple landscape characteristics that explore the interrelationships between the natural and cultural features of the landscape [8]. The recent definition is one which includes human processes - social, cultural and economic classification. Although, this definition is internationally accepted, it has not been tested within the Nigerian context.

Since landscape is recognized as a resource, it therefore becomes a variable to be considered in land use decisions [9]. A structured method of landscape assessment, linking description, classification, analysis and evaluation, usually provides an integrated framework within which decisions on land use management and advice can be debated [10]. The purpose of landscape assessment is to assist in the protection, management and planning of the natural environment. Previous studies indicate that tourist behaviours can be explained by destination image, place attachment, involvement in activities, tourist attitudes, subjective norms, and perceived control behaviour [11]. Destination images significantly affect the satisfaction and future behaviour of tourists who stay at coastal resorts in Spain [12]. It was also established that the destination image directly affects the quality of the trip, and indirectly, perceived value, satisfaction and future behavioural intentions of tourists visiting coastal destinations [13]. Within the Nigerian context, the satisfaction of tourists and visitors at a natural tourist attraction in Jos measured. In this connection, their perception of aesthetics, landscape, location, as well as awareness of the site were measured, and it was found out that only $50 \%$ of them were satisfied with the facilities that are provided [14]. The authors examined the interrelationship in tourist behaviours but did not identify how they relate to their perception or preferences for the landscape of the tourism destinations.

A theoretical framework that relates to landscape perception and assessment, is the Scenic Beauty Model (SBME). This model considers the relevance of physical features in evaluating a landscape [15]. The most recent position is that, scenic beauty judgments depend jointly on the perceived properties of the landscape and the judgmental criteria of the observer [16]. It however, does not 
consider the landscape's sense of place and place attachment which goes beyond the observer's perceived beauty or lack of it. Another important theoretical framework is the landscape perception theory [17] further to include other indices [18]. Its simplified model indicates landscape perception considered as a function of the interaction of humans and the landscape [19]. The human component encompasses past experience, knowledge, expectations, and the socio-cultural context of individuals and groups. The component of landscape includes both individual elements and entities of landscape. The interaction results in outcomes which in turn affect both the human and landscape components. This model, which is also comprehensive in discussing landscape perception, was adapted to the research in determining the place of human perception of the landscape with regards to tourism destination.

The conceptual framework adopted in the study (Figure 3), takes into consideration the following key issues: the sense of place as determined by its place attachment, landscape perception, the decision making process of the tourist in the selection of destination, especially as it affects tourist satisfaction, and the landscape characteristics of the tourism product. The framework also includes non-landscape issues and identifies three key variables that impact on landscape characteristics of the Lagos Lagoon and tourism. These include sense of place, landscape units, and social patterns which lead to the various forms of tourism which apply to the Lagos Lagoon.

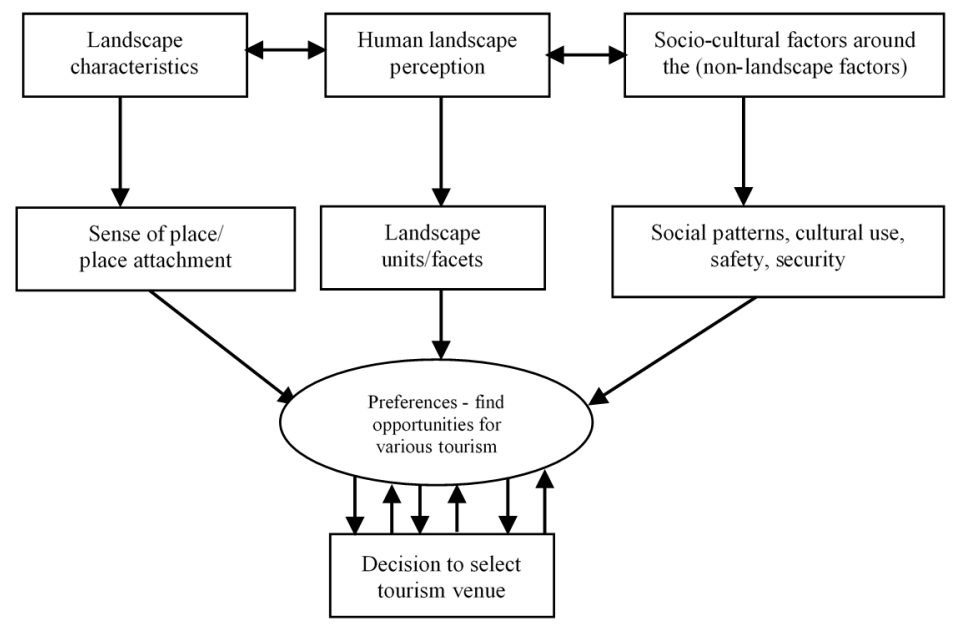

Figure 3: Conceptual model for the research.

\section{Methodology}

The methodology used for the study involves qualitative, quantitative, personal observation, and desktop study. The combination of qualitative and quantitative research made it possible to clinically explore the factors which contribute to expectations in a tourist destination. The landscape resources were identified by 
using secondary existing maps which were verified and upgraded by personal observation (via a field survey in which the existing features were recorded during a boat ride along the shores of the Lagos Lagoon). A quantitative survey was carried out at six different locations so as to determine respondents' perceptions and preferences using indices that were predetermined obtained from existing literature, data from interviews with professionals, and personal input. The qualitative phase consisted of in-depth interviews with experts on tourism, landscape and policy makers to arrive at the landscape assessment. Qualitative research helped to clarify the quantitative phase (i.e. survey design and data collection). It identified factors that impact on tourism development by using structured questionnaires and recorded interviews. Landscape assessment techniques involved sampling of perceptions and preferences of the public relating this with both professional and expert perceptions, using pictures of the site. Landscape mapping of the characteristics of the lagoon was determined from both literature and personal observation which guided the typologies used in carrying out the picture sorting of various aspects of the Lagos Lagoon.

Photo-questionnaires which are similar to those used by previous researchers were used to sample water tourism users and tourists at the study locations using purposeful random sampling method during public holidays and festive seasons $[20,21]$. Previous studies as well as the pilot study were used to determine the peak periods of patronage at the various destinations. Data from the Lagos State Ministry of Tourism was used to establish a minimum number of visitors to water tourism destinations in Lagos as 10,000,000. The sample size was selected based on the table for determining sample size, which indicated that the sample size should not be less than 384 for the total population involved [22]. In addition, 150 questionnaires were used at the two locations that had the highest number of people, while 75 were used at each of the four other sites.

\section{Results and discussions}

Various factors influence the patronage of the Lagos Lagoon waterfront for tourism and recreation. The study tried to establish what the key attractions were to the respondents by identifying the issues considered most important in the selection and usage of the various venues at the destination, especially as it concerns its natural assets. The results are shown in Figure 4 which identified the water and the provision of water games/sports at the venue as most important.

\subsection{Landscape Typology of the Lagos Lagoon Waterfront}

In evaluating the natural character of the Lagos Lagoon landscape, the study used the approach of human ecosystems model of functional landscape types [23]. The swampy mangrove landscape which is the most dominant in the Lagos Lagoon was mapped into five distinct types, based on the pattern of human settlements.

These include scenic quasi-natural landscapes (usually residential, institutional, and mixed with lush vegetation), hard urban fabric (mostly intense 


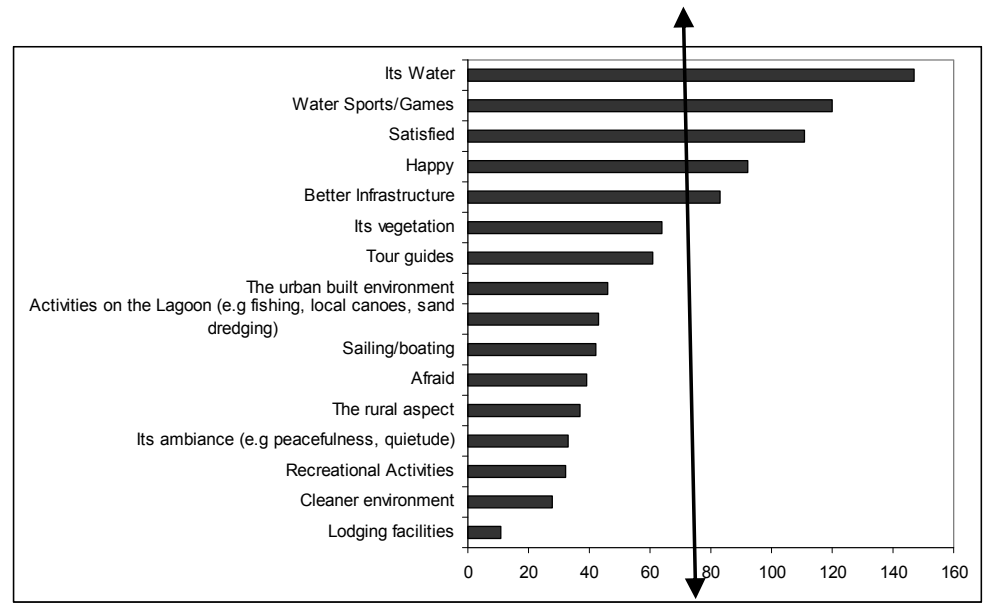

Figure 4: Frequency of factors that determine how a tourist selects a destination for tourism.

urban built-up edge, commercial markets, sand mining, saw milling, pollutants with little or no vegetation), slum residence (stilt and shanty housing), rural and natural settlements nearly pristine undeveloped landscapes as shown in Figure 5.
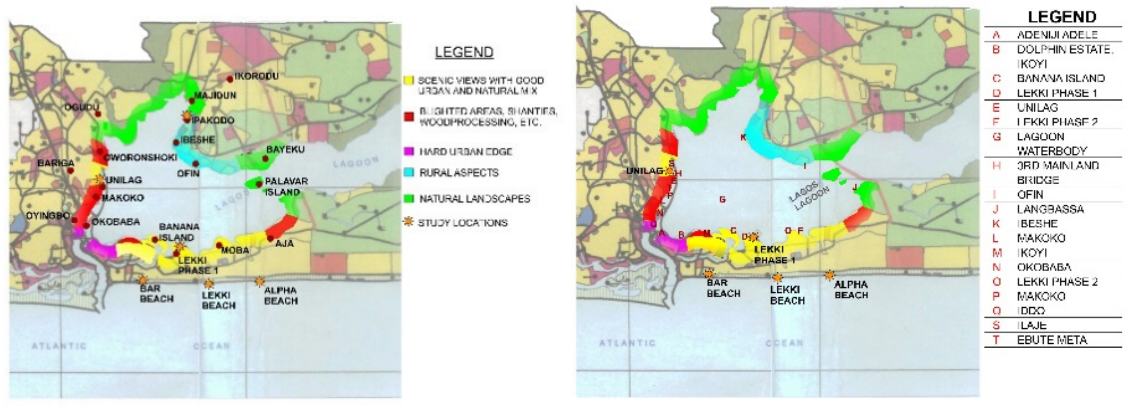

Figure 5: Landscape mapping of the Lagos Lagoon and location for pictures.

\subsection{Ranking of respondents' perception of the landscape characteristics of the Lagos Lagoon}

Ranking of landscape perception of the Lagos Lagoon: LB (Least Beautiful), A (Average), FB (Fairly Beautiful), B (Beautiful), EB (Extremely Beautiful).

The precise locations from where the pictures were taken are shown in Figure 5. Table 1 shows the ranking of the totally urban aspects. In the first set of pictures (Figure 6) comprises shots of totally urban aspects of the lagoon, the results show that they were all considered beautiful, with picture $\mathrm{C}$ (showing a high rise luxury building) having the highest score of 70 . It also had the highest score in the entire 20 pictures ranked by the respondents. 


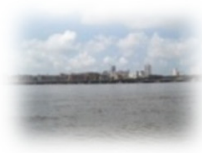

A

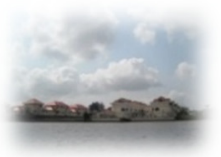

B

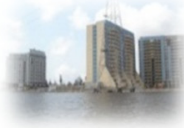

C

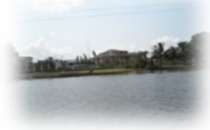

$\mathrm{D}$

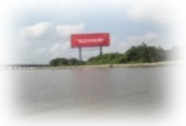

E

Figure 6: Totally urban pictures.

Table 1: Ranking of landscape perception of the Lagos Lagoon: totally urban.

\begin{tabular}{|c|c|c|c|c|c|c|c|c|c|c|c|c|c|c|}
\hline Picture & LB & $\mathbf{\%}$ & $\mathbf{A}$ & $\mathbf{\%}$ & $\mathbf{F B}$ & $\mathbf{\%}$ & $\mathbf{B}$ & $\mathbf{\%}$ & $\mathbf{E B}$ & $\mathbf{\%}$ & $\mathbf{T o t a l}$ & $\begin{array}{c}\text { Scale } \\
\text { mean }\end{array}$ & $\begin{array}{c}\text { Response } \\
\text { mean }\end{array}$ & $\mathbf{\%}$ \\
\hline $\begin{array}{c}\text { Ranking of } \\
\text { Picture A }\end{array}$ & 23 & 6.5 & 71 & 20.1 & 83 & 23.4 & 116 & 32.8 & 61 & 17.2 & 354 & 3.0 & 3.3 & 66 \\
\hline $\begin{array}{c}\text { Ranking of } \\
\text { Picture B }\end{array}$ & 33 & 9.3 & 76 & 21.5 & 96 & 27.2 & 110 & 31.2 & 38 & 10.8 & 353 & 3.0 & 3.1 & 62 \\
\hline $\begin{array}{c}\text { Ranking of } \\
\text { Picture C }\end{array}$ & 26 & 7.4 & 53 & 15.1 & 84 & 23.9 & 101 & 28.8 & 87 & 24.8 & 351 & 3.0 & 3.5 & 70 \\
\hline $\begin{array}{c}\text { Ranking of } \\
\text { Picture D }\end{array}$ & 28 & 8.0 & 68 & 19.3 & 97 & 27.6 & 107 & 30.4 & 52 & 14.8 & 352 & 3.0 & 3.2 & 64 \\
\hline $\begin{array}{c}\text { Ranking of } \\
\text { Picture E }\end{array}$ & 35 & 9.9 & 68 & 19.2 & 95 & 26.8 & 100 & 28.2 & 57 & 16.1 & 355 & 3.0 & 3.2 & 64 \\
\hline Total & $\mathbf{1 4 5}$ & $\mathbf{8 . 2 2}$ & $\mathbf{3 3 6}$ & $\mathbf{1 9 . 0 4}$ & $\mathbf{4 5 5}$ & $\mathbf{2 5 . 7 8}$ & $\mathbf{5 3 4}$ & $\mathbf{3 0 . 2 8}$ & $\mathbf{2 9 5}$ & $\mathbf{1 6 . 7 4}$ & & $\mathbf{3 . 0}$ & $\mathbf{3 . 3}$ & $\mathbf{6 6}$ \\
\hline
\end{tabular}

In the second set of pictures (Figure 7) comprising shots of different landscape elements of the lagoon, results show that they were predominantly considered beautiful except for picture J which had a score of 2.9.

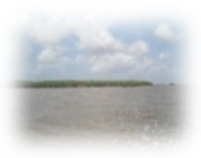

$\mathrm{F}$

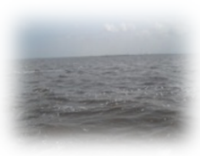

G

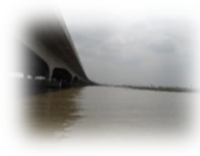

$\mathrm{H}$

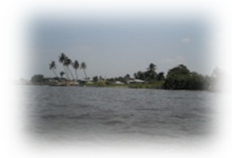

I

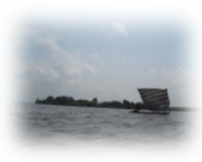

$\mathrm{J}$

Figure 7: Landscape elements pictures.

Table 2: Ranking of landscape perception of the Lagos Lagoon: landscape elements.

\begin{tabular}{|c|c|c|c|c|c|c|c|c|c|c|c|c|c|c|}
\hline Picture & $\mathbf{L B}$ & $\mathbf{\%}$ & $\mathbf{A}$ & $\mathbf{\%}$ & $\mathbf{F B}$ & $\mathbf{\%}$ & $\mathbf{B}$ & $\mathbf{\%}$ & $\mathbf{E B}$ & $\mathbf{\%}$ & $\mathbf{T o t a l}$ & $\begin{array}{c}\text { Scale } \\
\text { mean }\end{array}$ & $\begin{array}{c}\text { Response } \\
\text { mean }\end{array}$ & $\mathbf{\%}$ \\
\hline $\begin{array}{c}\text { Ranking of } \\
\text { Picture F }\end{array}$ & 29 & 8.1 & 68 & 19.0 & 114 & 31.8 & 82 & 22.9 & 65 & 18.2 & 358 & 3.0 & 3.2 & 64 \\
\hline $\begin{array}{c}\text { Ranking of } \\
\text { Picture G }\end{array}$ & 36 & 10.2 & 81 & 22.9 & 82 & 23.2 & 98 & 27.8 & 56 & 15.9 & 353 & 3.0 & 3.0 & 64 \\
\hline $\begin{array}{c}\text { Ranking of } \\
\text { Picture H }\end{array}$ & 45 & 12.8 & 97 & 27.6 & 66 & 18.8 & 103 & 29.3 & 41 & 11.6 & 352 & 3.0 & 3.0 & 60 \\
\hline $\begin{array}{c}\text { Ranking of } \\
\text { Picture I }\end{array}$ & 49 & 13.9 & 69 & 16.5 & 90 & 25.5 & 107 & 30.3 & 38 & 10.8 & 353 & 3.0 & 3.0 & 60 \\
\hline $\begin{array}{c}\text { Ranking of } \\
\text { Picture J }\end{array}$ & 54 & 15.3 & 78 & 22.2 & 84 & 23.9 & 104 & 29.5 & 32 & 9.1 & 352 & 3.0 & 2.9 & 58 \\
\hline Total & $\mathbf{2 1 3}$ & $\mathbf{1 2 . 0 6}$ & $\mathbf{3 9 3}$ & $\mathbf{2 2 . 2 4}$ & $\mathbf{4 3 6}$ & $\mathbf{2 4 . 6 4}$ & $\mathbf{4 9 4}$ & $\mathbf{2 7 . 9 6}$ & $\mathbf{2 3 2}$ & $\mathbf{1 3 . 1 2}$ & & $\mathbf{3 . 0}$ & $\mathbf{3 . 1}$ & $\mathbf{6 2}$ \\
\hline
\end{tabular}


In the third set of pictures (Figure 8) containing of shots of open spaces around the lagoon, the scores were generally low. The result showed that they were considered beautiful, except for Pictures K (showing fishing circles) and picture $\mathrm{M}$ (with mixed vegetation) which jointly had the lowest score of 58, as the least liked pictures in the group.

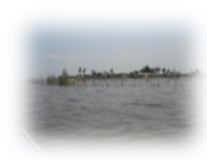

$\mathrm{K}$

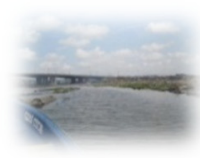

L

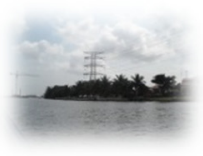

$\mathrm{M}$

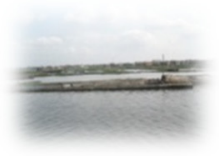

$\mathrm{N}$

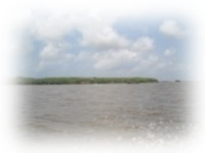

$\mathrm{O}$

Figure 8: Open spaces pictures.

Table 3: Ranking of landscape perception of the Lagos Lagoon: open spaces.

\begin{tabular}{|c|c|c|c|c|c|c|c|c|c|c|c|c|c|c|}
\hline Picture & LB & $\mathbf{\%}$ & $\mathbf{A}$ & $\mathbf{\%}$ & $\mathbf{F B}$ & $\mathbf{\%}$ & $\mathbf{B}$ & $\mathbf{\%}$ & $\mathbf{E B}$ & $\mathbf{\%}$ & $\mathbf{T o t a l}$ & $\begin{array}{c}\text { Scale } \\
\text { mean }\end{array}$ & $\begin{array}{c}\text { Response } \\
\text { mean }\end{array}$ & $\mathbf{\%}$ \\
\hline $\begin{array}{c}\text { Ranking of } \\
\text { Picture K }\end{array}$ & 63 & 17.2 & 85 & 23.2 & 81 & 22.1 & 98 & 26.7 & 40 & 10.9 & 367 & 3.0 & 2.9 & 58 \\
\hline $\begin{array}{c}\text { Ranking of } \\
\text { Picture L }\end{array}$ & 63 & 17.1 & 89 & 24.1 & 64 & 17.3 & 109 & 29.5 & 44 & 11.9 & 369 & 3.0 & 3.0 & 60 \\
\hline $\begin{array}{c}\text { Ranking of } \\
\text { Picture M }\end{array}$ & 59 & 16.0 & 82 & 22.3 & 81 & 22.0 & 115 & 31.3 & 31 & 8.4 & 368 & 3.0 & 2.9 & 58 \\
\hline $\begin{array}{c}\text { Ranking of } \\
\text { Picture N }\end{array}$ & 51 & 14.1 & 81 & 22.4 & 79 & 21.9 & 121 & 33.5 & 29 & 8.0 & 361 & 3.0 & 3.0 & 60 \\
\hline $\begin{array}{c}\text { Ranking of } \\
\text { Picture O }\end{array}$ & 52 & 14.4 & 65 & 18.0 & 93 & 25.8 & 98 & 27.1 & 53 & 14.7 & 361 & 3.0 & 3.1 & 62 \\
\hline Total & $\mathbf{2 8 8}$ & $\mathbf{1 5 . 7 6}$ & $\mathbf{4 0 2}$ & $\mathbf{2 2}$ & $\mathbf{3 9 8}$ & $\mathbf{2 1 . 8 2}$ & $\mathbf{5 4 1}$ & $\mathbf{2 9 . 6 2}$ & $\mathbf{1 9 7}$ & $\mathbf{1 0 . 7 8}$ & & $\mathbf{3 . 0}$ & $\mathbf{3 . 0}$ & $\mathbf{6 0}$ \\
\hline
\end{tabular}

The pictures (Figure 9) comprising shots of human and social activities around the lagoon had the lowest scores in the entire group of pictures. The picture with the lowest score in this group was picture $\mathrm{S}$ (showing slum housing on stilts) which was least liked pictures in the group and also among the entire 20 pictures ranked by the respondents.
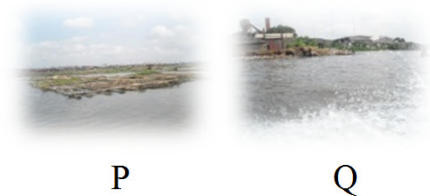

Q

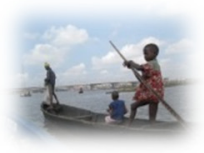

$\mathrm{R}$

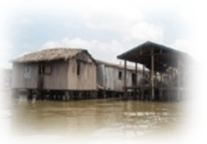

S

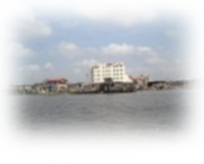

$\mathrm{T}$

Figure 9: Human and social activities pictures. 
Table 4: Ranking of landscape perception of the Lagos Lagoon: human and social activities.

\begin{tabular}{|c|c|c|c|c|c|c|c|c|c|c|c|c|c|c|}
\hline Picture & LB & $\mathbf{\%}$ & $\mathbf{A}$ & $\mathbf{\%}$ & $\mathbf{F B}$ & $\mathbf{\%}$ & $\mathbf{B}$ & $\mathbf{\%}$ & $\mathbf{E B}$ & $\mathbf{\%}$ & $\mathbf{T o t a l}$ & $\begin{array}{c}\text { Scale } \\
\text { mean }\end{array}$ & $\begin{array}{c}\text { Response } \\
\text { mean }\end{array}$ & $\mathbf{\%}$ \\
\hline $\begin{array}{c}\text { Ranking of } \\
\text { Picture P }\end{array}$ & 79 & 22.4 & 72 & 20.4 & 69 & 19.5 & 95 & 28.9 & 38 & 10.8 & 353 & 3.0 & 2.8 & 56 \\
\hline $\begin{array}{c}\text { Ranking of } \\
\text { Picture Q }\end{array}$ & 58 & 16.4 & 79 & 22.4 & 81 & 22.9 & 97 & 27.5 & 38 & 10.8 & 353 & 3.0 & 2.9 & 58 \\
\hline $\begin{array}{c}\text { Ranking of } \\
\text { Picture R }\end{array}$ & 64 & 18.5 & 91 & 26.3 & 65 & 18.8 & 89 & 25.7 & 37 & 10.7 & 346 & 3.0 & 2.8 & 56 \\
\hline $\begin{array}{c}\text { Ranking of } \\
\text { Picture S }\end{array}$ & 103 & 29.5 & 73 & 20.9 & 79 & 22.6 & 68 & 19.5 & 26 & 7.4 & 349 & 3.0 & 2.5 & 50 \\
\hline $\begin{array}{c}\text { Ranking of } \\
\text { Picture T }\end{array}$ & 68 & 19.6 & 52 & 15.0 & 88 & 25.4 & 79 & 22.8 & 60 & 17.3 & 347 & 3.0 & 3.0 & 60 \\
\hline Total & $\mathbf{3 7 2}$ & $\mathbf{2 1 . 2 8}$ & $\mathbf{3 6 7}$ & $\mathbf{2 1}$ & $\mathbf{3 8 2}$ & $\mathbf{2 1 . 8 4}$ & $\mathbf{4 2 8}$ & $\mathbf{2 4 . 4 8}$ & $\mathbf{1 9 9}$ & $\mathbf{1 1 . 4}$ & & $\mathbf{3 . 0}$ & $\mathbf{2 . 8}$ & $\mathbf{5 6}$ \\
\hline
\end{tabular}

Figure 10 shows the six factors considered important regarding the effects of the landscape characteristics. The landscape factor considered most significant is the clearance of the slum houses and similar blights on the shores of the lagoon. Handling the problem areas along the lagoon shores will help in influencing its acceptability for tourism. The issue of enhancing the physical properties of the lagoon needs to be addressed since the water is coloured, smelly and polluted [2] as this was the second most important factor. This makes it unsuitable for most water tourist activities as visitors can neither swim in it, nor have direct access to it due to one hygienic reason or the other. This is a paradox as respondents have identified the water as the lagoon's key attraction (Figure 4).

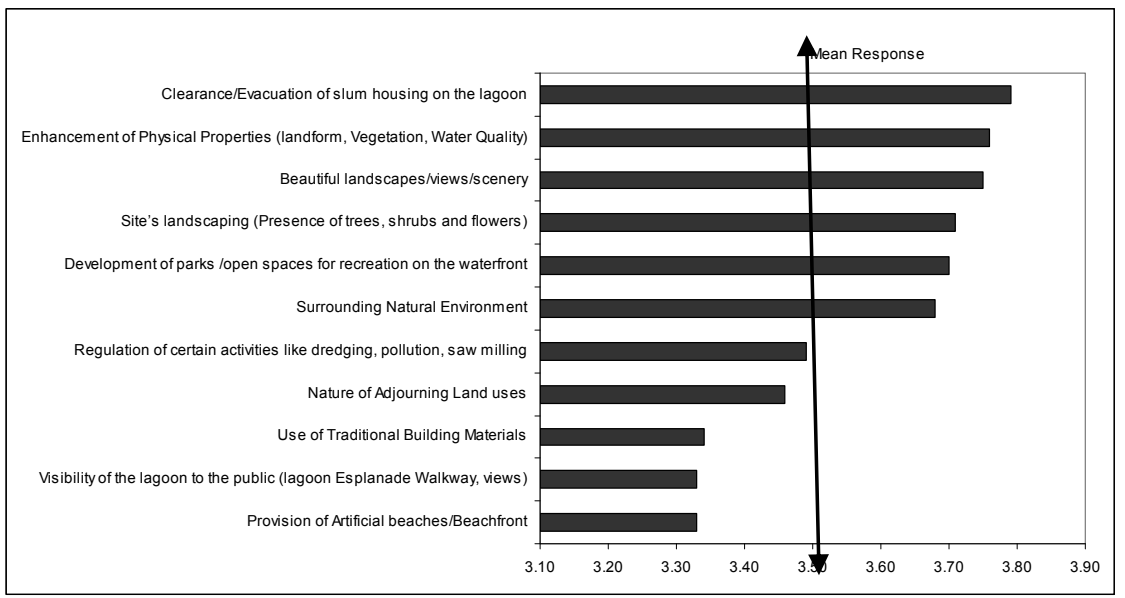

Figure 10: Chart of mean response of landscape characteristics of the Lagos Lagoon waterfront on tourism.

Another factor considered relevant by the respondents is the development of parks and open spaces for recreation along the waterfront. Currently, there are very few recreational spaces or parks directly adjacent to the shores of the lagoon. Such 
places would afford the general public an opportunity to directly interact with the lagoon. From the 31 factors identified in the questionnaire as influencing tourism in the Lagos Lagoon, the respondents identified eleven from among them as having the most significant effect on tourism by using principal component analysis with rotation method varimax. Regression analysis was applied to investigate the factor with the highest direct score on tourism (Table 5).

Table 5: Regression analysis of factors influencing the impact of landscape characteristics of the Lagos Lagoon for tourism.

\begin{tabular}{|c|c|c|c|c|c|}
\hline \multicolumn{6}{|c|}{ Regression Coefficients } \\
\hline & \multicolumn{2}{|c|}{$\begin{array}{l}\text { Unstandardized } \\
\text { Coefficients }\end{array}$} & \multirow{2}{*}{$\begin{array}{c}\begin{array}{c}\text { Standardized } \\
\text { Coefficients }\end{array} \\
\text { Beta }\end{array}$} & \multirow{2}{*}{$\mathrm{T}$} & \multirow[t]{2}{*}{ Sig. } \\
\hline & $\mathrm{B}$ & Std. Error & & & \\
\hline (Constant) & 0.827 & 0.077 & & 10.740 & 0.000 \\
\hline $\begin{array}{l}\text { Visibility of the lagoon to the public (lagoon } \\
\text { esplanade walkway, views) }\end{array}$ & 0.082 & 0.010 & 0.211 & 8.219 & 0.000 \\
\hline $\begin{array}{l}\text { Site's landscaping (presence of trees, shrubs and } \\
\text { flowers) }\end{array}$ & 0.079 & 0.011 & 0.203 & 7.529 & 0.000 \\
\hline Surrounding natural environment & 0.077 & 0.010 & 0.195 & 7.411 & 0.000 \\
\hline Beautiful landscapes/views/scenery & 0.086 & 0.010 & 0.229 & 8.606 & 0.000 \\
\hline $\begin{array}{l}\text { Regulation of certain activities like dredging, } \\
\text { pollution, saw milling }\end{array}$ & 0.054 & 0.010 & 0.141 & 5.374 & 0.000 \\
\hline $\begin{array}{l}\text { Development of parks/open spaces for recreation on } \\
\text { the waterfront }\end{array}$ & 0.078 & 0.011 & 0.190 & 7.010 & 0.000 \\
\hline Provision of artificial beaches/beach front & 0.068 & 0.010 & 0.177 & 7.009 & 0.000 \\
\hline Use of traditional building materials & 0.045 & 0.011 & 0.118 & 4.264 & 0.000 \\
\hline Nature of adjourning land uses & 0.065 & 0.011 & 0.160 & 5.838 & 0.000 \\
\hline Clearance/evacuation of slum housing on the lagoon & 0.042 & 0.010 & 0.108 & 4.064 & 0.000 \\
\hline $\begin{array}{l}\text { Enhancement of physical properties (landform, } \\
\text { vegetation, water quality) }\end{array}$ & 0.073 & 0.011 & 0.181 & 6.667 & 0.000 \\
\hline
\end{tabular}

Dependent variable: tourism score.

The p-values indicates that all the factors have significant effect on tourism, with the highest being beautiful landscapes/views/scenery while the lowest is clearance/evacuation of slum houses on the lagoon. Of all the choices highlighted the seven highest scores involve direct access to the lagoon either by way of beautiful scenery, visibility to the public, development of parks, and the provision of artificial beaches/beachfront.

\subsection{Landscape assessment of the Lagos Lagoon}

The Lagos Lagoon under study can be described as a predominant natural urban resource, with some mangrove forests and swampy wetlands. Due to its diverse nature, the lagoon can be used for various types of tourism in a manner that may engender appropriate and sustainable development. The results of the photoquestionnaires indicated several areas that ought not to be developed based on the public's perception of lack of suitability on account of existing problems like blights, slum houses, wrong land use, etc. Such areas will require rehabilitation to make them suitable for tourism development. Results of the survey also indicated 
a preference for urban agriculture for the lagoon waterfront which is currently going on in a haphazard manner. These activities ought to be properly regulated and planned to function side by side with tourism.

Based on the study of its landscape characteristics, the Lagos lagoon can be assessed for tourism as follows (Figure 11). Hard urban edge can be rehabilitated so as to create vegetation, while water edge can also be developed into esplanades with good views, accessibility and visibility to the lagoon. This is suitable for urban-style waterfront tourism development which has activities, parks, and opportunities for cultural displays. The aspects that currently have fairly scenic views will require more research to identify areas for neighbourhood parks, bicycle/jogging trails, and possibly themed parks. The blighted aspects will be suitable for clearance and rehabilitation to provide fresh venues for waterfront tourist developments that will attract both local and international traffic. The rural areas will be suitable for resort and conference tourism. The amelioration of the landscape of the natural aspects will ensure conservation if tourism must occur in such areas, the emphasis will be on ecotourism and other sustainable forms of it.

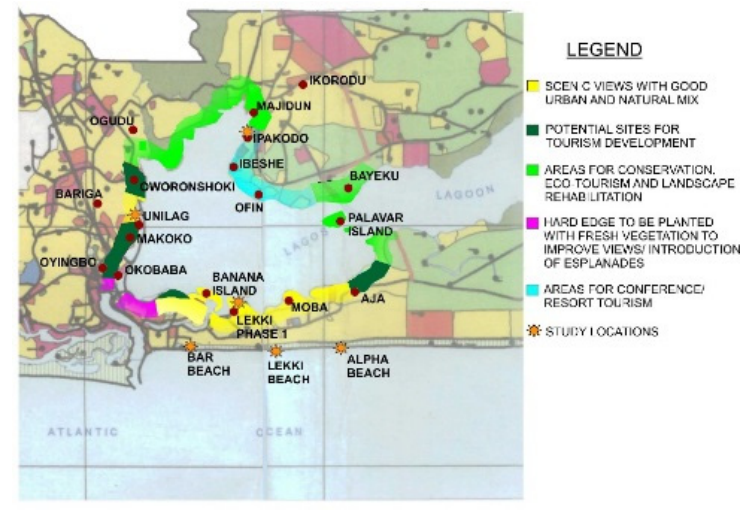

Figure 11: Landscape assessment of the Lagos Lagoon waterfront for tourism.

\section{Conclusion}

The natural features of the lagoon are important in its use as a tourist destination. Having examined the most critical issues that affect the use of the lagoon for tourism, the study recommends the re-evaluation of planning policies to show the importance of landscape and natural features of the lagoon in its tourism development. This will affect the current dredging, pollution, zoning of certain land uses that hinder the accessibility and visibility of the waterfront to the general public. In all the results, the respondents did not consider the lagoon suitable as a tourism destination due to its several shortcomings. A recurring problem in the attraction of tourists to the lagoon was the state of the water body itself. Urgent steps need to be taken to maintain the lagoon and make it as a tidy unpolluted resource. In fact, issues as dumping of refuge, indiscriminate dredging, sand filling 
of lagoonal shores for residential uses and channelling of both industrial and domestic waste should be addressed.

One of the major deterrents was identified as a lack of basic infrastructure. This includes access to the lagoon, both visual and physical. On the part of private investors, it is necessary for government to provide more incentives to encourage them to get involved in tourism by way of tax reduction, of tax, reduction in the costs of land, equity, etc. Most of the respondents who are of the view that there was nothing special about the lagoon and will be unwilling to pay to use its facilities the way they currently are, suggest that there is need to upgrade existing facilities. Results of the ranking of the pictures of the lagoon indicated that the slums were considered distasteful by most of the respondents. Clearance on slum was also rated high when the impact of the landscape on tourism was measured. From the results, the landscape of the lagoon, more than social factors and place attachment, has the most significant impact on the development of tourism. This, in essence, means that there is the need to engage in the realignment of priorities in land use planning so as to create and sustain more effective results.

\section{References}

[1] Chukwu, L. O. Ecological effects of human induced stressors on coastal ecosystems in Southwestern Nigeria. Proceedings of the International Oceanographic Institute (IOI) Pacem in Maribus (PIM) Conference held at the University of Western Cape: Cape Town, South Africa, pp. 61-70, 2002.

[2] Onyema, I., C. Pollution and the ecology of coastal waters of Nigeria. Dolps \& Bolps: Lagos, 2009.

[3] Nwilo, P. C., Peters, K. O. \& Badejo, O. T. Development of a Lagos Lagoon information System. Environmental Review, 3(2), pp. 403-408, 2009.

[4] Okoye, C. O., Onwuka S. U., \& Obiakor, M. O. Pollution survey in the Lagos Lagoon and its environmental consequences: A review. Tropical Built Environment, 1(1), pp. 41-54, 2010.

[5] Uduma-Olugu, N. \& Oduwaye, L. The regeneration of Lagos Lagoon waterfront for recreation and tourism. REAL CORP 2010, $15^{\text {th }}$ International Conference Proceedings: Vienna, pp. 759-764, 2010.

[6] Gnoth, J. Tourism motivation and expectation formation. Annals of Tourism Research, 24(2), pp. 283-304, 1997.

[7] Obiefuna, J. Human spatial behavior as a basis for outdoor design in Nigeria. Faculty of Environmental Sciences (University of Lagos) Special Publication, Series. Voll, Traditional/Cultural Environments \& Dwellings. University of Lagos, pp.11-23, 1994.

[8] Ndubuisi, F. Ecological Planning: A historical and comparative synthesis, John Hopkins University Press: Baltimore and London, 2002.

[9] Dearden, P. Philosophy, theory, and method in landscape evaluation. Canadian Geographer, 29, pp. 263-265, 1995.

[10] Cooper, A \& Murray, R. A structured method of landscape assessment and countryside management. Applied Geography, 12, pp. 319-338, 1992. 
[11] Lee, T., H. A structural model to examine how destination image, attitude, and motivation affect the future behavior of tourists. Leisure Sciences, 31, pp. 215-236, 2009.

[12] Bigné, J. E., Sánchez, M. I., \& Sánchez, J. Tourism image, evaluation variables and after purchase behavior: Interrelationship. Tourism Management, 22(6), pp. 607-616, 2001.

[13] Chen, C. F., \& Tsai, D. C. How destination image and evaluative factors affect behavioral intentions? Tourism Management, 28, pp. 1115-1122, 2007.

[14] Sati, Y. C. Architecture and Tourism: An appraisal of Solomon Lar amusement park, Jos. Architecture and Urbanization: Journal of the Nigerian Institute of Architects, 4(3), pp. 26-30, 2005.

[15] Daniel T. C., \& Boster, R. S. Measuring landscape aesthetics: The scenic beauty estimation method. USDA Forest Service, Research Paper RM-167. Ft. Collins, CO: USDA Forest Service, Rocky Mountain Forest and Range Experiment Station, 1976.

[16] Daniel, T. C. Whither scenic beauty? Visual landscape quality assessment in the $21^{\text {st }}$ century. Landscape and Urban Planning, 54(1-4), pp. 267-281, 2001.

[17] Zube, E. H., Sell, J. L., \& Taylor, J. G. Landscape perception: Research, application, and theory. Landscape Planning, 9(1), pp. 1-33, 1982.

[18] Gobster, P. H. An ecological aesthetic for forest landscape management. Landscape Journal 18(1), pp. 54-64, 1999.

[19] Zube, E.H., Brush, R.O. \& Fabos, J. Gy. (Eds). Landscape Assessment: Values, Perceptions and Resources. Dowden, Hutchinson and Ros: Stroudsburg, PA, 1975.

[20] Tveit, M. S. Indicators of visual scale as predictors of landscape preference; A comparison between groups. Journal of Environmental Management. 90(9), pp. 2882-2888, 2009.

[21] Fyhri, A., Jacobsen J.K.S. \& Tommervik, H. Tourist Landscape Perceptions and preferences in a Scandinavian coastal region. Landscape and Urban Planning, 91(4), pp. 202-211, 2009.

[22] Krejcie, R. V., \& Morgan, D. W. Determining sample size for research activities. Educational and Psychological Measurement, 30, pp. 607-610, 1990.

[23] Swaffield, S. A framework for landscape assessment. Landscape Review, 5(1), pp. 45-51, 1990. 